\title{
De psychologie van arbeid en gezondheid
}

Wilmar Schaufeli

$1.1 \quad$ Inleiding - 2

1.2 Wat is arbeids- en gezondheidspsychologie? - 2

1.3 Waarom psychologie van arbeid en gezondheid? - 5

1.3.1 Veranderingen in en rondom de arbeid -5

1.3.2 Sociaal-culturele veranderingen -7

1.3.3 Ontwikkelingen in Nederland - 9

1.4 De psychologie van arbeid en gezondheid als praktijkveld - 11

1.5 De psychologie van arbeid en gezondheid als onderzoeksveld - 14

1.6 De toekomst van de psychologie van arbeid en gezondheid - 18

Aanbevolen literatuur - 20 


\subsection{Inleiding}

De arbeids- en gezondheidspsychologie (A\&G-psychologie) is een van de jongste en meest dynamische loten aan de stam van de psychologie. Het is een samensmelting van de klinische psychologie, de gezondheidspsychologie en de A\&O-psychologie, die zich van origine bezighoudt met het disfunctioneren van mensen in arbeidsorganisaties. Daarnaast staan tegenwoordig ook het vergroten van de effectiviteit, het bevorderen van gezondheid en welzijn en het verhogen van de motivatie in de belangstelling, met andere woorden, het verbeteren van het functioneren van werknemers.

Deze beide aspecten hebben alles te maken met de januskop van de arbeid, die duidelijk zichtbaar wordt in de twee betekenissen die er in het Latijn aan worden gegeven: labor, werk als inspanning, belasting en moeite, en opus, werk als resultaat, uitdaging en zelfverwerkelijking. Vandaar ook dat arbeid door de Nederlandse filosoof Achterhuis (1984) een 'eigenaardig medicijn' is genoemd. Je kunt er ziek maar ook juist beter door worden, het is belastend maar tegelijkertijd ook uitdagend en het stompt af maar zorgt ook voor ontplooiing. Over deze beide zijden van de medaille gaat de A\&G-psychologie. En dit boek geeft daar een overzicht van, te beginnen met dit inleidende hoofdstuk.

In $>$ par. 1.2 wordt een nadere omschrijving gegeven van de A\&G-psychologie, waarbij onder meer een onderscheid wordt gemaakt tussen professie en wetenschap ofwel tussen praktijkveld en onderzoeksterrein. Nadat in $>$ par. 1.3 is ingegaan op de vraag waarom de A\&Gpsychologie zich de afgelopen jaren zo in de aandacht heeft mogen verheugen, worden in - par. 1.4 en $>$ par. 1.5 respectievelijk het praktijkveld en het onderzoeksterrein van de A\&Gpsychologie behandeld. Het hoofdstuk wordt afgesloten met $\downarrow$ par. 1.6, waarin een blik op de toekomst wordt geworpen.

\subsection{Wat is arbeids- en gezondheidspsychologie?}

De A\&G-psychologie heeft een betrekkelijk korte geschiedenis. Het Engelse equivalent 'occupational health psychology' werd voor het eerst gebruikt in 1990, om een nieuw vakgebied aan te duiden dat zich ontwikkelde op het snijvlak van klinische en gezondheidspsychologie enerzijds en A\&O-psychologie en 'public health' anderzijds. In datzelfde jaar besloten de American Psychological Association (APA) en het National Institute of Occupational Safety and Health (NIOSH) om dit nieuwe terrein gezamenlijk te stimuleren, onder meer door het organiseren van internationale conferenties, waarvan de eerste in 1990 in Washington plaatsvond onder de titel 'Work and well-being. In 1993 startten in de Verenigde Staten de eerste postdoctorale cursussen op het gebied van de A\&G-psychologie, in 1998 gevolgd door predoctorale opleidingen. De beide toonaangevende wetenschappelijke tijdschriften op het gebied van de A\&Gpsychologie zijn eveneens van tamelijk recente datum: het Europese Work \& Stress stamt uit 1987 en het Amerikaanse Journal of Occupational Health Psychology uit 1996. Ook het oprichten van een beroepsvereniging gebeurde eerder in Europa dan in Amerika, de European Academy of Occupational Health Psychology zag in 1999 het levenslicht en haar Amerikaanse evenknie, de Society of Occupational Health Psychology volgde zes jaar later in 2005.

Nederland loopt voorop bij de ontwikkeling van het vak. Reeds in 1987 werd de Commissie Klinische A\&O-psychologie van het Nederlands Instituut van Psychologen (NIP) opgericht, die inmiddels is omgedoopt tot Sectie A\&G-psychologie. En reeds vanaf het eind van de jaren tachtig van de vorige eeuw wordt er in de A\&O-curricula van de meeste Nederlandse en Vlaamse universiteiten aandacht besteed aan de A\&G-psychologie. Ook aan hbo-psychologieopleidingen bestaat er belangstelling voor de A\&G-psychologie. 
De A\&G-psychologie kan als volgt worden omschreven: De A\&G-psychologie is een psychologische discipline die zich bezighoudt met het bestuderen en bevorderen van welzijn en gezondheid op het werk vanuit de gedachte van een optimale afstemming tussen persoon en organisatie. Deze definitie behoeft op een aantal punten nadere toelichting. In de eerste plaats is de A\&G-psychologie zowel een wetenschapsgebied waarin welzijn en gezondheid op het werk wordt bestudeerd, als een praktijkveld waarin dit praktisch wordt bevorderd. Daarbij heeft de term welzijn overigens een dubbele betekenis; enerzijds heeft het betrekking op individueel welbevinden en anderzijds op bepaalde objectiveerbare kenmerken van de arbeid die geacht worden het individuele welbevinden te bevorderen. Daarbij kan gedacht worden aan werkkenmerken, zoals regelmogelijkheden, feedback, afwisseling of de aanwezigheid van sociale contacten. Met andere woorden, als de kwaliteit van de arbeid in orde is, zullen de werknemers zich ook gezond voelen. In de A\&G-psychologie gaat het zowel om het verbeteren van het individuele welbevinden als om het verbeteren van de kwaliteit van de arbeid.

In de bovenstaande definitie van A\&G-psychologie komt de term veiligheid niet voor, terwijl dat in andere omschrijvingen wel het geval is. Zo hanteert de APA/NIOSH de volgende definitie: 'Occupational health psychology concerns the application of psychology to improving the quality of work life, and to protecting and promoting the safety, health and well-being of workers.' De reden om het aspect veiligheid niet in onze definitie op te nemen, is dat dit in Nederland het exclusieve domein is van de veiligheidskunde, een technische discipline die door ingenieurs wordt beoefend. Dat neemt natuurlijk niet weg dat psychologische inzichten in de veiligheidskunde worden gebruikt en dat A\&G-psychologen en veiligheidskundigen in de praktijk nauw met elkaar samenwerken. Immers, veiligheid op het werk heeft alles te maken met gedrag van mensen - en dus met psychologie.

De term gezondheid dient in onze definitie in brede zin te worden opgevat, dus niet uitsluitend in termen van lichamelijke én geestelijke gezondheid, maar ook in termen van gezondheidsgedrag, zoals het gebruik van alcohol tijdens het werk, agressie en seksuele intimidatie, pesten, ziekteverzuim en arbeidsongeschiktheid. Bovendien staan wij in navolging van Warr (2007) een multidimensioneel begrip van geestelijke gezondheid voor, waarbij vier aspecten onderscheiden worden:

1. affectief welbevinden (je prettig voelen op het werk);

2. competentie (in staat zijn je werk goed te doen);

3. autonomie (eigen keuzen in je werk kunnen maken);

4. aspiratie (iets in je werk willen bereiken).

Met andere woorden, er is van geestelijke gezondheid sprake wanneer een werknemer zich prettig voelt, het werk goed aankan, zich vrij voelt om eigen keuzen te maken en gemotiveerd is om iets te bereiken. Het is deze - ideale - psychische toestand die de A\&G-psychologie nastreeft. Daarbij houdt de A\&G-psychologie echter ook nadrukkelijk rekening met de doelen van de organisatie. De A\&G-psychologie streeft naar een optimale afstemming tussen de belangen van werknemers en die van de organisatie. Dat wil zeggen dat de A\&G-psycholoog bij het bevorderen van het welzijn en de gezondheid van werknemers en bij het verbeteren van de kwaliteit van hun arbeid ook steeds de doelen van de organisatie (bijv. continuïteit van de onderneming, arbeidsproductiviteit en doelmatigheid) in ogenschouw zal nemen.

In de definitie van A\&G-psychologie wordt gesproken over 'werk' en 'organisatie'. Werk heeft daarbij niet zozeer betrekking op betaalde arbeid maar op arbeid in psychologische zin, dat wil zeggen, op een gestructureerde, doelgerichte activiteit met een zeker verplichtend karakter waarbij al dan niet met anderen waarde wordt gecreëerd. Zo gaat de A\&G-psychologie bijvoorbeeld ook over vrijwilligerswerk of mantelzorg, maar niet over sport en spel en vrije tijd. Desalniettemin zullen we ons in dit boek grotendeels beperken tot betaald werk, omdat dit nu 
eenmaal de dominante vorm is waarin arbeid zich in onze maatschappij voordoet, en omdat er - daardoor - ook het meest over bekend is. Verder dient de term organisatie in de definitie breed te worden opgevat. Er kan ook een klein familiebedrijf mee worden bedoeld, zoals een boerenbedrijf of een winkel waar slechts enkele mensen werken, al dan niet in gezinsverband.

En, last but not least, de A\&G-psychologie beperkt zich niet uitsluitend en alleen tot het domein van het werk, maar houdt zich ook bezig met de wederzijdse beïnvloeding van het werk met andere levenssferen, zoals de vrije tijd en de gezins- of thuissituatie. De psychologische en fysiologische effecten van arbeid zijn nu eenmaal niet onmiddellijk verdwenen wanneer er met werken wordt gestopt, terwijl andersom het privéleven van invloed is op het werk (zie $>$ H. 14).

Alhoewel de A\&G-psychologie vooral verankerd is in de klinische psychologie, de gezondheidspsychologie en de A\&O-psychologie, worden inzichten uit vrijwel alle andere psychologische disciplines gebruikt, zoals de functieleer (bijv. cognitieve informatieverwerking; zie $>$ H. 3), de psychofysiologie (bijv. stressonderzoek; zie $\neg$ H. 4), de sociale psychologie (bijv. groepsprocessen in organisaties; zie $>$ H. 6 en $\bullet$ H. 9), de persoonlijkheidsleer (bijv. individuele assessment en persoonlijkheidskenmerken; zie $>$ H. 5 en $>$ H. 15) en de ontwikkelingspsychologie (bijv. oudere werknemers; zie $>$ H. 22). Daarnaast zijn ook andere academische disciplines van belang, zoals de epidemiologie (over het vóórkomen van bepaalde klachten; zie H. 12), de methodologie (over het verrichten van onderzoek; zie $>$ H. 10 en H. 11), en de sociologie (over maatschappelijke groepen zoals vrouwen en allochtonen; zie H. 21 en $\neg$ H. 23). Met andere woorden, in de $A \& G$-psychologie is veel kennis verenigd die afkomstig is uit veel disciplines van binnen en buiten de psychologie.

Het kenmerkende van de A\&G-psychologie is voorts dat zij verschillende perspectieven hanteert. De A\&G-psychologie houdt zich niet alleen bezig met het individu, in de vorm van werknemer of leidinggevende, maar ook met sociale systemen waarbinnen het individu op het werk functioneert, zoals het team, de afdeling of de organisatie in zijn geheel. Bovendien is hierboven reeds vermeld dat de A\&G-psychologie zich niet uitsluitend beperkt tot de subjectieve kant van het functioneren van mensen in arbeidsorganisaties, maar daarbij ook de meer objectieve aspecten betrekt, zoals de aard van de arbeidstaak, de kenmerken van de functie en de structuur van de organisatie. Daarbij raakt de A\&G-psychologie aan de bedrijfs- en organisatiekunde, die zich bij uitstek toelegt op dit soort 'harde' aspecten van organisaties (zie $>$ H. 11 en $>$ H. 19).

Hetzelfde geldt voor indicatoren van welbevinden en gezondheid, want ook daarbij worden door de A\&G-psychologie zowel subjectieve als objectieve aspecten betrokken. Voorbeelden zijn welbevinden en ervaren gezondheid zoals gescoord op vragenlijsten (zie $>$ H. 5), het ziekteverzuim, personeelsverloop en de arbeidsongeschiktheid zoals geregistreerd door de organisatie (zie $\neg$ H. 12 en $\neg$. 20), en psychofysiologische metingen (zie $\neg$ H. 4). Ten slotte hanteert de $A \& G$-psychologie ook verschillende tijdsperspectieven: enerzijds is er aandacht voor het hier en nu, anderzijds wordt er vooruitgekeken als het bijvoorbeeld gaat om loopbanen van werknemers.

De unieke kern van de A\&G-psychologie ligt in het hanteren van de verschillende inzichten, perspectieven en methoden. Wil men bijvoorbeeld iets begrijpen van stress in organisaties om daaraan vervolgens iets te doen, dan zal niet alleen naar de psychologische, fysiologische en persoonseigenschappen van werknemers gekeken moeten worden, maar ook naar hun concrete taken en functies, relaties met hun collega's en leidinggevenden en naar de cultuur van het bedrijf. Kortom, de A\&G-psycholoog dient van vele markten thuis te zijn. Het is juist deze diversiteit die voor velen het beroep zo aantrekkelijk maakt. 
De bemoeienissen van de A\&G-psychologie zijn gericht op verschillende doelen, waarbij het - zoals we al eerder zagen - gaat om de optimale afstemming van persoon en organisatie. In de eerste plaats heeft de A\&G-psychologie een signalerende functie, dat wil zeggen, door gericht screeningsonderzoek ofwel vroegdiagnostiek is het mogelijk om bepaalde risicogroepen en risicofactoren op te sporen. Een voorbeeld hiervan is de wettelijk verplichte risicoinventarisatie en -evaluatie (RIE), die periodiek in alle organisaties moet worden uitgevoerd en die als basis dient voor maatregelen om welzijn en gezondheid van werknemers te bevorderen $($ zie $>$ H. 5 en $\neg$ H. 6).

Daarnaast houdt de A\&G-psychologie zich bezig met primaire en secundaire preventie (zie - H. 9). Bij primaire preventie wordt door middel van een aanpak bij de bron getracht om te voorkómen dat er gezondheids- of welzijnsproblemen ontstaan (bijv. door het dragen van oorbeschermers of door het invoeren van functioneringsgesprekken). Bij secundaire preventie is er sprake van beperking van de schade door tijdig en adequaat op te treden bij diegenen die de eerste symptomen van verminderde gezondheid of verminderd welzijn vertonen. In deze categorie vallen bijvoorbeeld allerlei trainingen en cursussen op het gebied van stressmanagement, sociale vaardigheden en tijdmanagement. Soms wordt ook de zogeheten tertiaire preventie onderscheiden, daarbij gaat het in feite om behandeling, dat wil zeggen, om het vermijden dat de problemen nóg groter worden en liever nog om te zorgen dat ze afnemen. Daarbij kan gedacht worden aan coaching, counseling en psychotherapie (zie $>$ H. 7). Ook behoort het gebied van de arbeidsre-integratie tot de A\&G-psychologie, dat wil zeggen, het herplaatsen van werknemers die zijn uitgevallen wegens ziekte of beperkingen (zie $>$ H. 8). Ten slotte wordt ook het bevorderen van welzijn en gezondheid tot de taken van de A\&G-psychologie gerekend. Met andere woorden, de A\&G-psychologie bestrijkt het gehele terrein van interventies, dat loopt van signalering, via gezondheidsbevordering, primaire en secundaire preventie naar behandeling en re-integratie.

Samenvattend: de A\&G-psychologie richt zich op gezondheid en welzijn van mensen in arbeidsorganisaties en maakt daarbij gebruik van kennis uit andere psychologische disciplines en daarbuiten. Daarbij opereert zij op het snijvlak van individu en organisatie en combineert zij verschillende perspectieven met elkaar. De A\&G-psychologie bestrijkt het gehele veld van interventies, dat loopt van de signalering van mogelijke problemen tot aan het terugleiden naar de arbeid van uitgevallen werknemers en het optimaliseren van gezondheid en welbevinden.

\subsection{Waarom psychologie van arbeid en gezondheid?}

Men kan zich afvragen waarom de A\&G-psychologie niet eerder het licht heeft gezien. Of anders gezegd, waarom kwam dit gebied pas op tegen het einde van de vorige eeuw? Een definitief sluitend antwoord op deze vraag is moeilijk te geven, maar er is wel een aantal ontwikkelingen aan te wijzen die een licht werpen op de populariteit van de A\&G-psychologie. Daarbij kan een onderscheid worden aangebracht in veranderingen in en rondom de arbeid, sociaal-culturele veranderingen, en in ontwikkelingen die zich specifiek in Nederland hebben voorgedaan.

\subsubsection{Veranderingen in en rondom de arbeid}

Intensivering van de arbeid

Volgens het Centraal Bureau voor de Statistiek (CBS) is het werktempo in Nederland van 1977 tot en met 1997 ieder jaar met ongeveer 1,5\% gestegen. Geen wonder dus dat werken steeds 
meer met topsport wordt vergeleken. Sinds 1997 is er overigens een stabilisering opgetreden; kennelijk is er een grens bereikt. Terwijl Nederland tot de eeuwwisseling in de Europese Unie (EU) nog een koppositie innam wat betreft werkintensiteit - dat wil zeggen snel en onder druk moeten werken - behoort het anno 2010 tot de middenmoot en moet het de Scandinavische landen, maar ook Duitsland, Italië, Griekenland en Oostenrijk voor laten gaan (Eurofound, 2010). Intensief moeten werken vormt een belangrijke oorzaak van welzijns- en gezondheidsproblemen (zie $\neg$ H. 2, $\neg$ H. 3 en $\neg$ H. 12).

\section{Verandering van de arbeidsinhoud}

Door technologische veranderingen (bijv. automatisering en informatisering) en veranderingen in de beroepsbevolking, zoals een stijgend opleidingspeil, werken steeds minder mensen met hun handen en steeds meer mensen met hun hoofd of met hun hart. Dat wil zeggen dat de fysieke belasting die kenmerkend is voor de agrarische en industriële sector, heeft plaatsgemakkt voor mentale en emotionele belasting die kenmerkend zijn voor het werken met informatie of met mensen (zie $>$ H. 13). Daarmee zijn ook de arbeidsgebonden gezondheidsrisico's verschoven van lichamelijke naar psychische klachten (zie ook $>$ H. 17).

\section{Organisatieveranderingen}

Er wordt weleens gesteld dat de enige constante factor in moderne arbeidsorganisaties verandering is. Allerlei ontwikkelingen zoals globalisering, informatisering, flexibilisering en de 24 uurseconomie nopen organisaties tot een continue aanpassing aan steeds wisselende omstandigheden, bijvoorbeeld door saneren ('downsizing'), afstoten van bedrijfsonderdelen ('outsourcing'), wegsnijden van het middenmanagement ('delayering'), of invoeren van Het Nieuwe Werken. Dergelijke organisatieveranderingen roepen in de regel tal van vragen op zoals: krijg $\mathrm{ik}$ ander werk? Word ik in een ander team geplaatst? Moet ik verhuizen? Krijg ik een andere baas? Verlies ik mijn baan? Vragen als deze roepen onzekerheid en daarmee spanning op en vormen zodoende een bron van psychische belasting (zie $>$ H. 25).

\section{Moderne bedrijfsvoering}

Nieuwe productiemethoden, zoals autonome taakgroepen of managementstrategieën als 'management by objectives', vergen de nodige aanpassing van werknemers. Een kenmerk van veel nieuwe concepten is dat verantwoordelijkheden laag in de organisatie worden gelegd. Zo hebben autonome groepen een grote mate van zelfstandigheid en eigen verantwoordelijkheid, niet alleen met betrekking tot de productie maar ook met betrekking tot de taakverdeling. Tevens worden werknemers in toenemende mate op hun individuele verantwoordelijkheden aangesproken, zoals bij het systeem van 'management by objectives', waarbij voor iedereen in de organisatie bepaalde doelen ('objectives') zijn geformuleerd die behaald moeten worden. De Nederlandse variant hiervan wordt ook wel aangeduid met resultaatgericht management (RGM). Niet alleen krijgen werknemers meer verantwoordelijkheden, maar ook hun leidinggevenden dienen zich aan te passen aan een vaak totaal andere wijze van aansturing, waarbij hun directe invloed afneemt. Moderne bedrijfsvoering kan een zware mentale druk leggen op werknemers en leidinggevenden.

\section{Aantasting van het psychologische contract}

Naast een schriftelijk arbeidscontract hebben werknemers ook een ongeschreven psychologisch contract met de organisatie waarvoor ze werken. Dat wil zeggen dat zij verwachtingen koesteren over een billijke verhouding tussen hun inspanningen ten behoeve van de organisatie en de materiële en immateriële beloning die daartegenover staat (zie $>$ H. 2). Werknemers die 
zich (extra) inzetten voor de organisatie, verwachten daarvoor meer terug dan alleen een billijk loon. De afgelopen jaren staat het psychologische contract onder toenemende druk, doordat er enerzijds steeds meer van werknemers wordt gevraagd (bijv. inzetbaarheid ofwel 'employability', betrokkenheid, flexibiliteit, zelfstandigheid en klantvriendelijkheid) terwijl er anderzijds steeds minder door organisaties wordt geboden. Vaste aanstellingen zijn schaars, loopbaanmogelijkheden zijn gering vanwege de platte organisatiestructuur en de professionele autonomie wordt aan banden gelegd door allerlei voorschriften en protocollen. Daarbij worden door voortdurende organisatieveranderingen, bijvoorbeeld als gevolg van fusies, regelmatig verwachtingen beschaamd. Ook ontdekken werknemers dat allerlei zaken die golden voor de generatie vóór hen (bijv. carrièrestappen, kunnen blijven tot je 65ste of juist daarvóór met een goede VUTregeling vertrekken) voor henzelf opeens niet meer gelden. Daardoor voelen zij zich teleurgesteld, want hun psychologische contract is geschonden. Wanneer investeringen en opbrengsten niet met elkaar in balans zijn, kan dit leiden tot psychische klachten, zoals burnout (zie $>$ H. 17).

\subsubsection{Sociaal-culturele veranderingen}

\section{Arbeidsparticipatie}

Bedroeg de arbeidsparticipatie van vrouwen in de jaren zestig van de vorige eeuw slechts $25 \%$, momenteel werkt $60 \%$ van alle vrouwen tussen de 15 en 64 jaar ten minste twaalf uur per week. Voor mannen bedraagt dit percentage $74 \%$. Hoewel de arbeidsparticipatie van Nederlandse vrouwen de afgelopen twee decennia met bijna $20 \%$ is gestegen, ligt deze nog steeds onder het niveau van de meeste andere westerse landen. Kenmerkend voor Nederland is het hoge aantal parttime werkende vrouwen. Maar liefst $70 \%$ van de vrouwen werkt minder dan 35 uur per week, tegen slechts $20 \%$ van de mannen (zie - H. 21). Overigens heeft de sterke toename van het aantal werkende vrouwen voor specifieke problemen gezorgd, zoals een verhoogde instroom van arbeidsongeschikten wegens psychische klachten (zie $>$ H. 12 en $\neg$ H. 20). Niet alleen is de arbeidsparticipatie van vrouwen gestegen, maar ook die van oudere werknemers: van 35 tot 51\%. In $>$ H. 22 wordt specifiek ingegaan op problemen van oudere werknemers. Werkte in 1996 slechts $40 \%$ van de ouderen tussen de 50 en 65 jaar, in 2009 was dat gestegen tot $57 \%$ (zie H. 22). De komende jaren zal het aantal oudere werknemers verder toenemen, mede in verband met de verhoging van de pensioengerechtigde leeftijd. Ten slotte is er de afgelopen decennia een sterk groeiende groep niet-westerse allochtone werknemers op het toneel verschenen - momenteel ruim $11 \%$ van de bevolking en in 2020 naar schatting $13 \%$ - met eigen specifieke problemen (zie $>$ H. 23).

\section{Opkomst van de dienstensector}

Aan het begin van de twintigste eeuw werkte $31 \%$ van de beroepsbevolking in de agrarische sector, aan het einde van diezelfde eeuw was dat nog maar $2 \%$. Het aandeel van de beroepsbevolking dat werkzaam is in de industrie is eveneens gedaald, zij het niet zo dramatisch: van $24 \%$ naar $19 \%$. Daartegenover staat een explosieve groei van de dienstensector (bijv. zorg, onderwijs, banken, verzekeringen) van $36 \%$ naar momenteel $73 \%$. Daarmee scoort Nederland samen met België, Luxemburg, Zweden, Denemarken en Groot-Brittannië het hoogst van alle EU-landen, waar gemiddeld zo'n $67 \%$ van de beroepsbevolking in de dienstensector werkzaam is. Kenmerkend voor deze sector is het contact met klanten, cliënten, patiënten, leerlingen of burgers, en de emotionele belasting die daaruit voortvloeit (zie $>$ H. 13). Met name in de gezondheids- en welzijnszorg en in het onderwijs komt veel psychische problematiek voor, die vaak de aanleiding vormt voor arbeidsongeschiktheid (zie H. 12). 


\section{Verruiming van het ziektebegrip}

In de loop van de vorige eeuw zijn steeds meer zaken die tot dan toe als normaal onderdeel van leven golden, voorwerp geworden van de gezondheids- en welzijnszorg. In dit verband wordt ook wel van 'protoprofessionalisering' gesproken. Daarmee wordt het verschijnsel bedoeld dat medische en psychologische begrippen worden gehanteerd om bepaalde alledaagse toestanden en ervaringen te duiden, die daardoor binnen het bereik van professionele hulpverleners komen. Die begrippen worden door mensen zelf gehanteerd en worden hen - via allerlei media - door diezelfde professionals aangereikt. Anders dan weleens is gesuggereerd, is daarbij niet zozeer sprake van een welbewuste strategie van professionals om zodoende hun eigen markt te creëren, maar van een socioculturele onderstroom van psychologisering. Steeds meer alledaagse ervaringen, gevoelens en mentale toestanden worden aangeduid met professioneel jargon. Voorbeelden daarvan zijn stress, overspannenheid en burnout, maar ook subassertiviteit, verlegenheid, chronische vermoeidheid, ADHD, postnatale depressie, en fobie. Voor de goede orde, hiermee is dus niet gezegd dat dit alles niet bestaat of dat er sprake is van 'aanstellerij'. Het gaat om reële ervaringen die ook in vroegere tijden bestonden, maar letterlijk niet als zodanig werden benoemd en (h)erkend omdat het vocabulaire daarvoor ontbrak. Men kan dus stellen dat het ziektebegrip in de loop van de tijd steeds ruimer is geworden. Of, andersom geformuleerd, dat de bandbreedte van wat als 'normaal' wordt beschouwd steeds smaller is geworden.

\section{Toegenomen verwachtingen}

Het lijkt er sterk op dat de verwachtingen die de moderne mens aan het werk (en aan het leven in het algemeen) stelt, geleidelijk steeds hoger zijn geworden. De tijd dat werk eerst en vooral inkomen en zekerheid betekende, ligt ver achter ons. Tegenwoordig worden er veel meer eisen aan het werk gesteld. Het moet leer- en ontwikkelingsmogelijkheden bieden, uitdagend en zinvol zijn, je moet carrière kunnen maken, met leuke en interessante collega’s samenwerken en een sympathieke baas hebben. Ook zijn met het stijgende opleidingsniveau - Nederlandse werknemers behoren tot de best opgeleiden in de EU - en met krapte op de arbeidsmarkt de verwachtingen ten aanzien van secundaire arbeidsvoorwaarden verder toegenomen. Op zichzelf zijn dergelijke verlangens uiteraard gerechtvaardigd, maar de kans op desillusie is recht evenredig met de hoogte van de verwachtingen die men koestert (zie $>$ H. 17).

\section{Individualisering}

Terwijl mensen in vroeger dagen deel uitmaakten van allerlei sociale netwerken (bijv. familie, buurt, kerk, vakbond, vereniging en politieke partij) die bepaalde rolpatronen oplegden op basis van traditie, religie en sociaaleconomische klasse, geldt dit in veel mindere mate voor de dag van vandaag. Tegenwoordig moet men zelf zijn eigen rollen invullen en eigen sociale netwerken kiezen, opbouwen en onderhouden. Dit vergt veel inspanning en (sociale) vaardigheden en daarover beschikt niet iedereen in gelijke mate. Tegelijkertijd staan mensen er nu meer dan vroeger alleen voor, omdat veel traditionele sociale verbanden zijn weggevallen. Zo neemt Nederland na Zweden (47\%), Denemarken (39\%), Finland (39\%) en Duitsland (38\%) met $34 \%$ een Europese koppositie in wat betreft het aantal alleenstaande huishoudens, hekkensluiter is Spanje met $14 \%$. Dat leidt tot minder voorbeeldgedrag en tot minder daadwerkelijke sociale steun. Die verminderde sociale steun maakt het omgaan met moeilijke situaties en gebeurtenissen, ook op het werk, meer belastend (zie ook $>$ H. 2).

\section{Uitholling van de professionele autoriteit}

Van een aantal beroepen, zoals dat van arts, leerkracht en politieagent, is de natuurlijke autoriteit die traditioneel uit hun positie als beroepsbeoefenaar voortvloeide, gaandeweg verloren 
gegaan. Hetzelfde geldt overigens voor buschauffeurs, treinconducteurs, cabinepersoneel en baliepersoneel. Het is waarschijnlijk niet toevallig dat er juist in deze beroepen veel psychische klachten voorkomen. Men wordt niet meer vanzelfsprekend met respect bejegend. Dit respect moet tegenwoordig verdiend worden door bekwame en tactische inzet van sociale vaardigheden en door emotionele arbeid (zie H. 13). De mensen in onze huidige maatschappij zijn mondiger en assertiever geworden en accepteren het natuurlijke overwicht dat artsen, leerkrachten en politieagenten tot voor kort hadden niet zonder meer. Door sociologen is wel geopperd dat in onze maatschappelijke instituties de traditionele (autoritaire) bevelshuishouding heeft plaatsgemaakt voor een (democratische) onderhandelingshuishouding. Dat impliceert bijvoorbeeld dat leidinggevenden veel meer dan voorheen over sociale vaardigheden als luisteren, empathie en humor dienen te beschikken (zie ook $\neg$ H. 7). Bij gebrek hieraan is de kans op psychische problemen groot.

\subsubsection{Ontwikkelingen in Nederland}

\section{Arbowetgeving}

De invoering van de Arbowet in 1983 heeft in Nederland een impuls gegeven aan de ontwikkeling van de A\&G-psychologie (zie www.arboportaal.nl). Naast gezondheid en veiligheid werd aanvankelijk welzijn als zelfstandig doel van beleid in de wet genoemd. Echter, bij de wetswijziging van 1998 werd dit begrip weer uit de Arbowet geschrapt. Desalniettemin rept de wet nog steeds, ook na de laatste wijziging in 2007 , over psychosociale arbeidsbelasting (PSA) waaronder zaken als werkdruk, agressie, geweld, seksuele intimidatie en pesten worden verstaan (zie $>$ H. 24). Volgens de Arbowet is iedere werkgever verplicht om te zorgen voor gezondheid en veiligheid op het werk. Aanvankelijk waren werkgevers wettelijk verplicht om een contract met een arbodienst af te sluiten, maar sinds 2005 is deze verplichting in het kader van de deregulering vervallen. Bij arbodiensten werken in de regel bedrijfsartsen, veiligheidskundigen, arbeidshygiënisten en arbeids- en organisatiedeskundigen (A\&O-deskundigen). Deze laatste beroepsgroep, die zich vooral richt op de relatie tussen werk en welzijn, is in 1994 door de wetgever gecreëerd en bestaat voor het grootste deel uit psychologen. In de praktijk overlapt het werkveld van $A \& O$-deskundigen sterk dat van $A \& G$-psychologen, en veel kennis uit de A\&G-psychologie wordt door deze en andere arboprofessionals toegepast.

\section{Psychische arbeidsongeschiktheid}

Sinds de invoering van de Wet op de arbeidsongeschiktheidsverzekering (WAO) in 1967 is het aantal arbeidsongeschikten explosief toegenomen tot bijna 10\% van de beroepsbevolking in 1999. Daarna is een daling ingezet tot minder dan $8 \%$ in 2011. Met name de afgelopen jaren is het aantal arbeidsongeschikten sterk gedaald, om precies te zijn met $23 \%$ sinds 2004 (zie - H. 12). Dit heeft vooral te maken met de invoering van de Wet verbetering poortwachter in 2002, die als doel heeft om het ziekteverzuim en de arbeidsongeschiktheid in te dammen en de Wet werk en inkomen naar vermogen (WIA) in 2006, de opvolger van de WAO. Opmerkelijk is dat de meeste werknemers vanwege psychische klachten worden afgekeurd. Traditioneel gaat het daarbij om circa een derde van het aantal afkeuringsgevallen. Sinds 2009 is dat aandeel echter opgelopen tot circa $40 \%$ in 2011. In absolute aantallen gaat het daarbij om bijna 400.000 werknemers. Ook bij afkeuring in verband met aandoeningen van het bewegingsapparaat - de op een na grootste diagnostische categorie met ruim $25 \%$ in 2011 - zijn vaak psychosociale factoren in het spel, zoals lage-rugpijn, 'Repetitive Strain Injury' (RSI) en klachten aan nek en schouders (KANS). Met andere woorden, de grote omvang van psychische arbeidsonge- 
schiktheid heeft de aandacht in Nederland gericht op psychosociale arbeidsrisico's, een terrein waarmee de A\&G-psychologie zich bij uitstek bezighoudt (zie H. 2). Andere Europese landen tellen een minder groot aantal (psychisch) arbeidsongeschikten, hetgeen waarschijnlijk mede veroorzaakt wordt door verschillen in socialeverzekeringsstelsels en een andere dynamiek tussen overheid en sociale partners. De WAO heeft in ons land lang het aureool gehad van een goede, humane en betaalbare manier om werknemers die niet meer nodig waren van inkomsten te voorzien. Vandaar dat deze wet is vervangen door de veel soberder WIA.

\section{Gezamenlijke verantwoordelijkheid van werkgevers, werknemers en overheid}

Het verbeteren van arbeidsomstandigheden en het verminderen van ziekteverzuim en arbeidsongeschiktheid wordt in Nederland gezien als een gezamenlijke verantwoordelijkheid van werkgevers, werknemers en overheid. Wel is het zo dat de overheid in de loop van de tijd steeds meer is teruggetreden en zich nu eigenlijk alleen nog maar bezighoudt met wetgeving, inclusief controle en handhaving door de arbeidsinspectie. Zo speelde de overheid aanvankelijk een actieve rol bij de totstandkoming van zogenoemde arboconvenanten, waarin afspraken werden gemaakt over arbeidsrisico's, en re-integratie van zieke of arbeidsongeschikte werknemers. Echter, sinds de laatste wijziging van de Arbowet in 2007 laat de overheid dit aan werkgevers en werknemers over. In plaats van arboconvenanten waarin concrete te behalen doelen, zoals vermindering van werkdruk of ziekteverzuim waren vastgelegd, zijn de wat minder stringente arbocatalogi gekomen. Daarin geven werkgevers en werknemers op eigen initiatief aan hoe ze zullen voldoen aan de eisen die de overheid aan veilig en gezond werken stelt. Een arbeidscatalogus wordt in de regel op brancheniveau samengesteld en bevat allerlei technieken en methoden, 'best practices', normen en praktische handleidingen voor veilig en gezond werken. Deze kunnen uiteraard ook betrekking hebben op psychosociale arbeidsrisico's, die de oorzaak vormen van stress en ziekteverzuim.

\section{Hoge kosten}

Hoewel er geen recente betrouwbare schattingen bestaan van de kosten die psychisch disfunctioneren in organisaties met zich meebrengt, heerst het idee dat de kosten aan de hoge kant zijn. Te denken valt daarbij aan ziekteverzuim- en arbeidsongeschiktheidsuitkeringen, medische consumptie, personeelsverloop, productieverlies en vervangingskosten in de vorm van uitzendkrachten, en de kosten van extra training en (bij)scholing. De totale maatschappelijke kosten voor ziekteverzuim en arbeidsongeschiktheid werden in 2001 geraamd op maar liefst 12 miljard euro, waarvan circa 4 miljard voor rekening komt van psychische aandoeningen (zie H. 12). Voor 1995 is berekend dat psychische aandoeningen en aandoeningen van het bewegingsapparaat samen $86 \%$ van het arbeidsgebonden ziekteverzuim voor hun rekening nemen, waarmee destijds tussen de 1,36 miljard en 2,93 miljard euro gemoeid was. De kosten van arbeidsgebonden WAO-uitval voor beide typen aandoeningen werd in dat jaar op 2,34 miljard euro geschat (voor alle WAO-diagnosen tezamen was dit 2,92 miljard euro), en de medische kosten op nog eens 0,25 miljard euro. Tezamen kostten de beide meest voorkomende arbeidsgebonden aandoeningen dus tussen de 3,95 en 5,52 miljard euro. Meer recente, globale schattingen uit respectievelijk 2006 en 2011 geven aan dat de blootstelling aan psychosociale risico's op het werk de Nederlandse staat jaarlijks om en nabij 3 miljard euro kost, hetgeen correspondeert met 1,5\% van het bruto nationaal product (zie $>$ H. 12). Met andere woorden, psychosociale blootstelling en werkgerelateerde psychische aandoeningen vormen niet alleen een probleem voor het individu of voor de organisatie, maar het is ook een financieel-economisch probleem voor de samenleving in haar geheel. Vandaar de wijziging die er het afgelopen decennium heeft plaatsgevonden van het stelsel van sociale zekerheid met het oog op volumevermin- 
dering en dus kostenreductie. Als zodanig vormt het streven naar vermindering van verzuim en arbeidsongeschiktheid een impuls voor het nieuwe vakgebied van de A\&G-psychologie dat kan bijdragen aan het besparen op dergelijke kosten.

\section{Lange traditie}

Anders dan in de meeste andere landen kent Nederland een lange traditie op het vlak van overspannenheid (ook wel aangeduid met de Franse term 'surmenage'), die teruggaat tot het einde van de negentiende eeuw. Vooral na 1960 werd deze medische diagnose populair bij huisartsen en bedrijfsartsen. Dit vormt wellicht ook de verklaring waarom het uit Amerika overgewaaide begrip 'burnout' zo snel voet aan de grond heeft gekregen in Nederland. Er is dus in Nederland een vruchtbare bodem aanwezig waarop de A\&G-psychologie kan gedijen. Dat komt overigens niet alleen doordat er bij een zekere traditie kan worden aangesloten, maar ook doordat er een uitgebreid netwerk van instituties aanwezig is (bijv. ambulante geestelijke gezondheidszorg, eerstelijnsgezondheidszorg, arbodiensten), er uitvoerige wetgeving op het vlak van psychosociale arbeidsomstandigheden is en de werkgerelateerde psychische problematiek een grote maatschappelijke omvang heeft.

\subsection{De psychologie van arbeid en gezondheid als praktijkveld}

De wortels van de A\&G-psychologie als praktijkveld zijn nauw verbonden met de beide wereldoorlogen. Zo trok de vermoeidheid van industriearbeiders tijdens de Eerste Wereldoorlog, met name in munitiefabrieken, de aandacht van het Engelse parlement. Deze installeerde de Industrial Fatigue Research Board, die met voorstellen diende te komen om dit euvel, dat vele slachtoffers eiste door fatale ongevallen, te bestrijden. Voorts vestigden beide wereldoorlogen de aandacht van klinisch psychologen en psychiaters op het verschijnsel van de acute en traumatische stress. In de Eerste Wereldoorlog werd de zogenaamde 'shellshock' beschreven, een psychologische uitputtingsreactie die optreedt als gevolg van blootstelling aan extreem belastende oorlogsomstandigheden zoals spervuur en bombardementen. In de Tweede Wereldoorlog werd dit verschijnsel ook wel met gevechtsneurose ('combat neurosis') of gevechtsmoeheid ('combat fatigue') aangeduid. Er werden gedetailleerde beschrijvingen van ziektebeelden gemaakt, die het gevolg waren van de extreme belasting waaraan geallieerde infanteriesoldaten, Amerikaanse gevechtspiloten en burgerslachtoffers van de bombardementen op Londen tijdens de Tweede Wereldoorlog waren blootgesteld.

Van systematische aandacht voor werkgerelateerde psychische klachten was tot de laatste decennia van de vorige eeuw echter nauwelijks sprake. Een uitzondering vormt de Tavistock Clinic in Londen, waar vanaf de jaren vijftig van de vorige eeuw een psychoanalytische benadering werd gehanteerd om werkgerelateerde psychische problematiek te bestrijden. Overigens stond het Tavistock Institute of Human Relations, waarvan de kliniek deel uitmaakte, ook aan de wieg van de organisatiegerichte aanpak om welbevinden en gezondheid op het werk te bevorderen. De klassieke studies die eind jaren veertig van de vorige eeuw door dit instituut in de Britse kolenmijnen werden uitgevoerd, vormden de basis voor de zogenaamde sociotechnische benadering. Deze gaat ervan uit dat stressreacties het product zijn van het sociale systeem waarbinnen de werknemer functioneert. De sociotechniek is een praktische methodiek die gebruikt wordt om de kwaliteit van de arbeid, en daarmee de gezondheid en het welbevinden van werknemers, te bevorderen.

Pas in de laatste twee decennia van de vorige eeuw is de A\&G-psychologie tot volle wasdom gekomen, voornamelijk als gevolg van de ontwikkelingen zoals die in par. 1.3 zijn beschre- 
ven. Men zou kunnen zeggen dat de A\&G-psychologie inmiddels volwassen is geworden en een eigen plaats heeft opgeëist in de dienstverlening. De A\&G-psycholoog vervult vandaag de dag verschillende taken, waarbij het meestal om een combinatie van verschillende typen werkzaamheden gaat. Een A\&G-psycholoog houdt zich in de praktijk voornamelijk met de volgende onderdelen bezig:

- Assessment. Dit is een wat bredere term dan diagnostiek, waarbij het gaat om het identificeren van een ziekte, symptoom of syndroom. Assessment betreft het op systematische en methodische wijze identificeren van allerlei soorten van problemen en mogelijkheden, die zich zowel voordoen op individueel niveau (bijv. overspanning, burnout en bevlogenheid), teamniveau (bijv. conflicten en samenwerking) als organisatieniveau (bijv. organisatiecultuur, werkdruk en ziekteverzuim). Dit houdt ook in dat de terugkoppeling in de vorm van een schriftelijke rapportage op verschillende niveaus plaatsvindt: individueel, groepsgewijs en organisatiebreed. Een bijzonder voorbeeld is het individuele preventief medisch onderzoek (PMO), voorheen periodiek arbeidsgezondheidskundig onderzoek (PAGO) genoemd, en de organisatiebrede risico-inventarisatie en -evaluatie (RIE), die beide in de Arbowet zijn vastgelegd (zie $>$ www.arboportaal.nl). In deel II van dit boek wordt nader op assessment ingegaan.

- Individuele begeleiding en behandeling. Het palet van individuele begeleiding en behandeling is tamelijk breed en strekt zich uit van het optimaliseren van het functioneren van werknemers en leidinggevenden (coaching), via lichtere vormen van begeleiding van werknemers die overspannen zijn of dreigen te worden (counseling), tot en met psychotherapie en re-integratie van werknemers met burnout of andere ernstige vormen van werkgerelateerde problematiek (zie $>$ H. 7 en $>$ H. 8). Overigens wordt er ook vaak in groepen gewerkt, maar anders dan bij bijvoorbeeld teambuilding richt de aandacht zich steeds op het individuele groepslid en op de als belastend ervaren organisatiefactoren (bijv. werkdruk).

- Training. Bij training kan het zowel gaan om het aanleren van individuele vaardigheden als om groepsprocessen. Voorbeelden van individuele vaardigheidstrainingen zijn assertiviteitstraining, socialevaardigheidstraining en training in tijdmanagement. Groepstrainingen kunnen betrekking hebben op het verbeteren van de communicatie, het vergroten van de groepscohesie, het verbeteren van de samenwerking en het vergroten van het probleemoplossend vermogen.

- Advisering. A\&G-psychologen vervullen dikwijls een adviserende rol, meestal ten aanzien van het hogere management. Maar ook het middenmanagement en de ondernemingsraad kunnen van advies worden gediend. Deze advisering heeft in de regel betrekking op het verminderen van het ziekteverzuim en de arbeidsongeschiktheid, het verminderen van psychische klachten, het verbeteren van de kwaliteit van de arbeid, het verhogen van de motivatie en het welbevinden van werknemers en het verbeteren van de manier van leidinggeven.

- Onderzoek. In een praktische setting is onderzoek (d.w.z. het verwerven van kennis) nooit een op zichzelf staand doel. Integendeel, het dient steeds een praktisch doel, zoals het stellen van een goede (organisatie)diagnose, het evalueren van een interventie of het onderbouwen van een advies. Met andere woorden, onderzoek vormt steeds een onderdeel van een andere kernactiviteit van de A\&G-psycholoog.

Hoeveel A\&G-psychologen er in Nederland zijn en waar ze precies werken, is niet bekend. Een indicatie van de omvang van het werkveld is te vinden in het feit dat de Sectie A\&G-psychologie met ruim twaalfhonderd leden de een na grootste sectie van de Sector A\&O van het NIP 
is. Voorts bestaat er sinds 1 oktober 2000 bij het NIP een Registratieregeling psycholoog van arbeid en gezondheid, die tot doel heeft de kwaliteit van het handelen van de A\&G-psycholoog te waarborgen en te bevorderen. Om in het register te worden opgenomen, moet aan een aantal eisen aan vooropleiding, cursorisch onderwijs, werkervaring en supervisie worden voldaan (voor verdere informatie zie www.psynip.nl).

A\&G-psychologen zijn op tal van plaatsen werkzaam, zoals bij arbodiensten (soms met een aanvullende opleiding als A\&O-deskundige), bij organisatieadvies-, trainings- en selectiebureaus, in de eerste- en tweedelijns geestelijke gezondheidszorg, en bij re-integratiebedrijven en commerciële instellingen voor curatieve zorg. Ook zijn A\&G-psychologen in toenemende mate actief als zelfstandig gevestigde. In hun werk hebben zij te maken met vier arbokerndisciplines, de bedrijfsarts, de veiligheidskundige, de A\&O-deskundige en de arbeidshygiënist (zie - box 1.1). Deze zijn respectievelijk verantwoordelijk voor de gezondheid, de veiligheid en het welzijn, en voor de fysieke arbeidsomstandigheden in het bedrijf. Daarnaast zijn ook ergonomen werkzaam, die zich bezighouden met de juiste afstemming tussen mens en machine. Hierbij kan ook aan computers (en software) worden gedacht, een gebied dat steeds meer aandacht krijgt in de vorm van cognitieve ergonomie.

In een wat breder verband hebben A\&G-psychologen dikwijls te maken met professionals uit de (geestelijke) gezondheidszorg, zoals huisartsen, eerstelijnspsychologen, psychotherapeuten en psychiaters, en met professionals uit de sfeer van de sociale verzekering, zoals verzekeringsartsen die arbeidsongeschiktheidsclaims beoordelen en arbeidsdeskundigen die adviseren over werkaanpassing bij werknemers met een handicap of aandoening. Ten slotte werken A\&G-psychologen uiteraard in organisaties nauw samen met lijnmanagers en met deskundigen op het gebied van Human Resources. Traditioneel houdt Human Resources Management (HRM) zich vooral bezig met de formele aspecten van het personeelsbeleid, zoals bij aanstelling, ontslag, loopbaan, ziekteverzuim en re-integratie. Maar recentelijk zien we dat HRM zich in toenemende mate bezighoudt met de meer psychologische kanten van het functioneren van mensen in arbeidsorganisaties, zoals het bevorderen van motivatie en bevlogenheid. Dat betekent dus dat het traditionele onderscheid tussen arbozorg en HRM steeds meer vervaagt. Een voorbeeld hiervan is het 'Integrale Gezondheidsmanagement' (IGM), waarbij niet alleen wordt gekeken naar wat werknemers niet meer kunnen of willen (het arboperspectief), maar ook naar wat werknemers juist wel kunnen en willen (het HRM-perspectief).

\section{Box 1.1 Arbokerndisciplines}

- Bedrijfsarts. Sociaal-geneeskundige (medisch specialist) die gespecialiseerd is in de lichamelijke en geestelijke gezondheid in relatie tot werk, en die preventief, begeleidend en soms ook curatief werkzaam is.

- Arbeidshygiënist. Ingenieur (post-hbo of postacademisch) die gespecialiseerd is in het meten en beoordelen van chemische, biologische en fysische arbeidsomstandigheden (straling, lawaai, trillingen, binnenklimaat) en in ondersteuning bij het vinden van oplossingen.

- Veiligheidskundige. Ingenieur (post-hbo of postacademisch) die gespecialiseerd is op het terrein van fysieke veiligheid, zoals preventie van brand en ontploffingen en het opstellen van veiligheidsvoorschriften bij het werken met gevaarlijke machines en toxische stoffen.

- A\&O-deskundige. Sociale wetenschapper met een postacademische of post-hboopleiding die gespecialiseerd is in psychische belasting door werk en daarmee verband houdende organisatorische vraagstukken. 


\subsection{De psychologie van arbeid en gezondheid als onderzoeksveld}

Het onderzoeksgebied dat momenteel bekend staat als A\&G-psychologie heeft zijn wortels in onderzoek naar vermoeidheid en mentale belasting en in fysiologisch stressonderzoek. De Duitser Emil Kraepelin en de Italiaan Angelo Mosso worden beschouwd als de voorlopers van het arbeidspsychologische belastingsonderzoek. Zij verrichtten aan het einde van de negentiende eeuw laboratoriumonderzoek naar de aantasting van de prestatiecapaciteit, bijvoorbeeld door proefpersonen drie tot vier uur achtereen rekensommen te laten maken. Vervolgens werd het aantal fouten dat zij maakten uitgezet tegen de tijd, waardoor een zogenoemde prestatievervalcurve werd verkregen. Deze prestatievervalcurve werd opgevat als een operationalisering van vermoeidheid. Immers, hoe langer het tijdsinterval, des te meer fouten er ten gevolge van vermoeidheid worden gemaakt.

Omstreeks 1920 voerde de Amerikaanse fysioloog Walter Cannon als eerste stressexperimenten uit. Hij stelde mensen en dieren in het laboratorium bloot aan allerlei belastende omstandigheden (bijv. kou, zuurstofgebrek en een laag bloedsuikergehalte) en observeerde vervolgens hun fysiologische reacties. Op grond van zijn experimenten postuleerde Cannon een dynamisch aanpassingsmechanisme, de 'homeostase', dat ervoor zorgt dat het interne fysiologische evenwicht bewaard blijft onder wisselende externe omstandigheden. Ruim twee decennia later kwam de Hongaars-Canadese fysioloog Hans Selye op grond van soortgelijke experimenten tot de conclusie dat er sprake is van een stereotiep, gefaseerd verlopend fysiologisch reactiepatroon dat onafhankelijk is van de specifieke vorm van de belasting. Dit zogenoemde algemene aanpassingssyndroom ('general adaptation syndrome'; GAS) bestaat uit verschillende functionele fysiologische veranderingen, zoals verhoging van de hartslag en de bloeddruk en toename van de maagsecretie, en kan op den duur tot volledige uitputting van het organisme leiden. Aan welke stressor het organisme ook werd blootgesteld, steeds volgde dezelfde reactie: het GAS.

Selye staat ook wel bekend als de vader van het stressonderzoek omdat hij de term stress heeft geïntroduceerd. Dat deed hij overigens met terugwerkende kracht pas ná de Tweede Wereldoorlog. Daarbij maakte hij trouwens als niet-Engelstalige een kardinale fout: hij sprak van stress (de kracht die op een lichaam wordt uitgeoefend), maar bedoelde eigenlijk strain (het resultaat van die kracht, ofwel de reactie op stress in de vorm van het GAS). Sindsdien zitten we opgescheept met de spraakverwarring rondom het begrip stress. Evenals in het alledaagse taalgebruik slaat de term stress bij Selye op een negatieve reactie, terwijl het woord zelf eigenlijk betrekking heeft op de oorzaak, in dit verband de uitlokkende, belastende situatie.

Tot het einde van de Tweede Wereldoorlog werd stress uitsluitend als een fysiologisch verschijnsel beschouwd. De eerste laboratoriumonderzoeken naar psychologische stress werden in het begin van de jaren vijftig van de vorige eeuw in opdracht van de Amerikaanse luchtmacht uitgevoerd door Richard Lazarus, die later bekend zou worden als de grondlegger van de invloedrijke stress- en copingtheorie. De organisatiepsychologie is zich pas tijdens en vooral na de Tweede Wereldoorlog gaan toeleggen op onderzoek naar stress in organisaties. Kort na de Tweede Wereldoorlog verscheen The American soldier (Stouffer e.a., 1949), een zeer gedetailleerde studie waarin uitvoerig aandacht werd besteed aan de relatie tussen organisatiekenmerken en het welbevinden van militairen. Een belangrijke les uit deze studie was dat bij stressreacties van mensen in organisaties ook rekening gehouden moet worden met sociaalpsychologische processen, zoals sociale vergelijking.

Vooral vanaf het midden van de jaren zestig van de vorige eeuw nam het psychologische stressonderzoek in organisaties een hoge vlucht, mede gestimuleerd door het baanbrekende werk aan het Amerikaanse Institute for Social Research te Ann Arbor. Daar werkten Robert 
Tabel 1.1. Typen A\&G-onderzoek

\begin{tabular}{|c|c|c|c|c|c|}
\hline & $\begin{array}{l}\text { hypothesetoet- } \\
\text { send onderzoek }\end{array}$ & $\begin{array}{l}\text { beschrijvend } \\
\text { onderzoek }\end{array}$ & $\begin{array}{l}\text { ontwerp- } \\
\text { onderzoek }\end{array}$ & $\begin{array}{l}\text { interventie- } \\
\text { onderzoek }\end{array}$ & $\begin{array}{l}\text { organisatieon- } \\
\text { derzoek }\end{array}$ \\
\hline oriëntatie & theoriegestuurd & \multicolumn{4}{|c|}{ probleemgestuurd } \\
\hline proces & empirische cyclus & \multicolumn{2}{|c|}{ non-cyclisch } & \multicolumn{2}{|c|}{ regulatieve cyclus } \\
\hline methode & \multicolumn{2}{|c|}{ empirisch-wetenschappelijk } & \multicolumn{3}{|c|}{$\begin{array}{l}\text { empirisch-wetenschappelijk, actieonderzoek, case } \\
\text { studies }\end{array}$} \\
\hline doel & verklaring & 'feiten' & gereedschap & evaluatie & verandering \\
\hline medium & $\begin{array}{l}\text { wetenschap- } \\
\text { pelijk tijdschrift, } \\
\text { vaktijdschrift }\end{array}$ & $\begin{array}{l}\text { bedrijfsrapport, } \\
\text { vaktijdschrift }\end{array}$ & \multicolumn{2}{|c|}{ vaktijdschrift } & bedrijfsrapport \\
\hline $\begin{array}{l}\text { primaire } \\
\text { doelgroep }\end{array}$ & $\begin{array}{l}\text { wetenschappelijk } \\
\text { forum }\end{array}$ & $\begin{array}{l}\text { organisatie, } \\
\text { beroepsbeoe- } \\
\text { fenaars }\end{array}$ & \multicolumn{2}{|c|}{ beroepsbeoefenaars } & organisatie \\
\hline
\end{tabular}

Kahn en zijn collega's de gedachte uit dat werkstress vooral samenhangt met de wijze waarop sociale rollen in arbeidsorganisaties zijn gestructureerd. In het begin van de jaren zeventig werd het zogenoemde Michigan Model door Charles de Wolff in Nederland geïntroduceerd, waar het eerst aan de Universiteit in Leiden en daarna in Nijmegen als basis diende voor het eerste Nederlandse onderzoek naar werkstress. Daarbij werd gebruikgemaakt van de uit het Amerikaans vertaalde en voor Nederland bewerkte Vragenlijst Organisatie Stress (VOS). Vooral vanaf de jaren negentig kreeg het onderzoek op het gebied van arbeid en gezondheid een sterke impuls doordat er aanzienlijke onderzoeksubsidies ter beschikking werden gesteld. Enerzijds bevorderde het Ministerie van Sociale Zaken en Werkgelegenheid allerlei toegepaste onderzoeksprojecten ten behoeve van het ontwerpen van betrouwbare instrumenten en effectieve interventies. Dit vanwege het feit dat er met de invoering van de Arbowet in 1994 plotseling een grote behoefte ontstond aan 'evidence-based' gereedschap waar arboprofessionals in de praktijk mee aan de slag konden gaan. Dergelijk gereedschap, bijvoorbeeld in de vorm van vragenlijsten voor het inventarisaren van psychosociale risico's, en procedures en interventies om psychische klachten en ziekteverzuim te voorkomen, was niet of nauwelijks voorhanden. Anderzijds bevorderden NWO en veel universiteiten wetenschappelijk onderzoek naar de achtergronden van stress in organisaties. Een voorbeeld daarvan is het grootschalige onderzoeksprogramma 'Psychische Vermoeidheid in de Arbeidssituatie' (1998-2004) waaraan zeven universiteiten deelnamen en in het kader waarvan meer dan dertig proefschriften zijn verschenen (Evenblij, 2004). Mede dankzij deze ondersteuning, maar ook omdat er in Nederland een uitgebreid praktijkveld aanwezig is waarin wetenschappelijke inzichten kunnen worden toegepast, behoort het Nederlandse A\&G-onderzoek tot de wereldtop.

Als wetenschapsgebied is de A\&G-psychologie deels theoretisch en deels meer praktisch georiënteerd; met andere woorden, zij is zowel theorie- als probleemgestuurd (zie $\mathbf{0}$ Tabel 1.1). Dat wil zeggen dat A\&G-onderzoek zich enerzijds richt op het verklaren en begrijpen van welbevinden en gezondheid op het werk, en anderzijds op het verbeteren ervan. Er is dus sprake van kennis en kunde. Er kunnen vijf verschillende typen A\&G-onderzoek worden onderscheiden (zie - Tabel 1.1). 
Het theoriegestuurde onderzoek volgt de zogenoemde empirische cyclus, waarbij achtereenvolgens een hypothese wordt geformuleerd, empirische gegevens worden verzameld en de hypothese statistisch wordt getoetst. Hierbij kan bijvoorbeeld worden gedacht aan onderzoek naar de effecten van een onbillijke behandeling door de organisatie op het ziekteverzuim van werknemers. Een hypothese zou kunnen zijn dat werknemers die zich onbillijk door de organisatie behandeld voelen, meer verzuimen dan diegenen die zich niet onbillijk behandeld voelen. Door vragenlijstgegevens over de ervaren onbillijkheid van werknemers in verband te brengen met hun geregistreerde ziekteverzuim, kan deze hypothese worden getoetst.

Probleemgestuurd onderzoek volgt daarentegen meestal een zogeheten regulatieve cyclus, waarbij achtereenvolgens een probleem wordt geformuleerd, een interventie wordt ontworpen, uitgevoerd en geëvalueerd (zie ook $\mathbf{0}$ Figuur 11.1). De interventie kan zowel betrekking hebben op een individuele persoon als op een groep. Voorbeelden zijn respectievelijk onderzoek door middel van gevalsstudies (casestudy's) naar het effect van een burnoutbehandeling en onderzoek naar de effectiviteit van een stressmanagementtraining. Effectiviteitsonderzoek kan met behulp van een (quasi-)experimenteel onderzoeksontwerp geschieden, waarbij naast een experimentele groep die de behandeling of training ontvangt ook een controlegroep wordt gebruikt die geen interventie ontvangt. Door bijvoorbeeld het verschil in ziekteverzuim vóór en na de training te vergelijken met dat van de controlegroep kan een wetenschappelijk onderbouwde uitspraak over het effect van de training worden gedaan (zie $>$ H. 10). Bij organisatiebreed onderzoek wordt in de regel gebruikgemaakt van de methode van actieonderzoek, al dan niet in combinatie met een gevalsstudie. Organisaties zijn namelijk dynamische systemen die voortdurend in verandering zijn en zich moeilijk laten dwingen in het keurslijf van een empirischwetenschappelijk experiment. Het belangrijkste kenmerk van actieonderzoek is dat de onderzoeker zelf deel uitmaakt van het veranderingsproces dat wordt bestudeerd. Onderzoek en veranderingsproces zijn niet van elkaar gescheiden maar beïnvloeden elkaar wederzijds. In een organisatiebreed ziekteverzuimproject wordt bijvoorbeeld op grond van de terugkoppeling van ervaringen van de deelnemers de verzuimtraining aan leidinggevenden tussentijds aangepast (voor gevalsstudies, interventieonderzoek en actieonderzoek zie ook $>$ H. 11).

Probleemgestuurd onderzoek kan echter ook non-cyclisch van aard zijn, dat wil zeggen, dat het noch de empirische cyclus van het hypothesetoetsend onderzoek volgt, noch de regulatieve cyclus van het interventie- of organisatieonderzoek. In dat geval gaat het om beschrijvend onderzoek dat tot doel heeft bepaalde feiten boven water te halen ('fact finding'), dan wel om ontwerponderzoek waarbij het gaat om het maken van gereedschap ('tools') in de vorm van instrumenten, richtlijnen en procedures. Het ontwerpen van op wetenschappelijke leest geschoeide instrumenten maakt het voor A\&G-psychologen mogelijk om 'evidence-based' te werken. Hoewel er geen theoretische bijdrage wordt geleverd, is er wel degelijk sprake van wetenschap, omdat er volgens de wetenschappelijke spelregels van systematiek, precisie, objectiviteit, verificatie en replicatie gewerkt wordt.

Een voorbeeld van beschrijvend onderzoek is de al eerdergenoemde RIE. Concrete vragen die bij dergelijk beschrijvend onderzoek opduiken zijn: wijkt het geconstateerde ziekteverzuim af van het (op grond van branche, geslacht, leeftijd) te verwachten ziekteverzuim? Hoe hoog is het ziekteverzuim vanwege psychische klachten? Hebben vrouwen meer last van stressklachten dan mannen? Hoe sterk hangen arbeidssatisfactie en prestatie met elkaar samen? Verzuimen werknemers die veel burnoutklachten hebben vaker dan diegenen die deze klachten niet hebben? Door het verzamelen en wetenschappelijk analyseren van empirische gegevens kan een antwoord op dergelijke vragen worden gegeven. 
Voorbeelden van ontwerponderzoek zijn het construeren van een valide en betrouwbare vragenlijst om werkstressoren te meten, het opstellen van betrouwbare diagnostische richtlijnen voor werkgerelateerde psychische stoornissen en het formuleren van criteria voor gezond werk (zie $>$ H. 5). Soms zal er bij ontwerponderzoek, evenals bij interventieonderzoek, ook gebruik worden gemaakt van casestudies en actieonderzoek.

Elk type onderzoek kent een eigen favoriet medium waarmee de relevante doelgroep wordt bereikt. Hypothesetoetsend onderzoek wordt in eerste instantie gepubliceerd ten behoeve van het wetenschappelijk forum en wel in wetenschappelijke tijdschriften en boeken (zie $>$ box 1.2). Wat meer populaire versies van wetenschappelijke artikelen verschijnen soms in vaktijdschriften, zoals De Psycholoog, Arbomonitor, Gids voor Personeelsmanagement en Medisch Contact, die zich vooral richten op beroepsbeoefenaars. Als het beschrijvende onderzoek in opdracht van derden is verricht, vindt er een terugrapportage plaats in de vorm van een bedrijfsrapport. Dergelijk onderzoek kan ook in een vaktijdschrift worden gepubliceerd en zelfs in wetenschappelijke tijdschriften. De resultaten van interventieonderzoek worden doorgaans eveneens in vaktijdschriften gepubliceerd, terwijl organisatieonderzoek in de regel in bedrijfsrapporten beschreven wordt. In principe kunnen overigens alle typen onderzoek in wetenschappelijke tijdschriften worden gepubliceerd, mits zij voldoen aan de daar geldende criteria.

\section{Box 1.2 Relevante wetenschappelijke tijdschriften}

De meest specifieke internationale tijdschriften op het gebied van A\&G-psychologie zijn Journal of Occupational Health Psychology, Work \& Stress en International Journal of Stress Management.

In Nederland bestaan geen specifieke tijdschriften op het gebied van arbeid en gezondheid. Gedrag en Organisatie is organisatiepsychologisch georiënteerd, en het medische Tijdschrift voor Sociale Geneeskunde en Tijdschrift voor Verzekeringsgeneeskunde komen het dichtst in de buurt. Verder kan het Tijdschrift voor Ergonomie genoemd worden.

Op het gebied van de A\&O-psychologie kunnen worden genoemd: Journal of Applied Psychology, Journal of Occupational and Organizational Psychology, Journal of Vocational Behavior, Journal of Organizational Behavior, Applied Psychology: An International Review en het European Journal of Work and Organizational Psychology. In deze tijdschriften wordt regelmatig over A\&G-thema's gepubliceerd.

Op het gebied van gezondheidspsychologie en psychosomatiek kunnen worden genoemd: Health Psychology, Psychology and Health, Psychosomatic Medicine, Behavioural Medicine, Social Science and Medicine, Anxiety, Stress and Coping, en Stress \& Health. In deze tijdschriften gaat het vaak om stress in relatie tot ziekte en minder om werkgebonden stress.

Op het gebied van bedrijfsgezondheid kunnen worden genoemd: International Archives of Occupational and Environmental Medicine, Journal of Occupational and Environmental Medicine, Occupational Medicine, Occupational and Environmental Medicine en het Scandinavian Journal of Work, Environment and Health. In deze tijdschriften wordt over psychosociale risico's en stressgerelateerde aandoeningen gepubliceerd.

Op het gebied van management kunnen worden genoemd: Academy of Management Journal, Journal of Business and Psychology, Journal of Managerial Psychology en Journal of Management. 


\subsection{De toekomst van de psychologie van arbeid en gezondheid}

Op grond van de ontwikkelingen die in $>$ par. 1.3 zijn geschetst, is te verwachten dat het belang van een gedragswetenschappelijke benadering van gezondheid, welbevinden en ziekte in relatie tot de arbeid voorlopig zal blijven groeien. Daarmee rust een grote verantwoordelijkheid op de schouders van zowel onderzoekers als beroepsbeoefenaars. Om deze verantwoordelijkheid ten volle te kunnen waarmaken, is er niet alleen dringend behoefte aan meer kennis, inzicht en ervaring, maar ook aan 'feiten', richtlijnen en procedures, kortom, aan goed gereedschap voor het praktisch handelen van de A\&G-psycholoog.

Hoe ziet de onderzoeksagenda voor de toekomst er uit? Er zal verder moeten worden gewerkt aan het vergroten van het inzicht in de psychologische processen die een rol spelen bij welbevinden en gezondheid op het werk. Daarbij gaat het niet zozeer om beschrijvende modellen waarin een aantal variabelen met elkaar in verband worden gebracht (zie H. 2), maar om verklarende theorieën waarbij een inhoudelijk verband in de vorm van een psychologisch mechanisme wordt blootgelegd. Dergelijke modellen zijn nog steeds tamelijk schaars in de A\&Gpsychologie. In de regel komt het vaak neer op leentjebuur spelen bij de sociale psychologie (bijv. de billijkheidstheorie), klinische psychologie (bijv. de leertheorie), cognitieve psychologie (bijv. de informatieverwerkingsmodellen) en motivatietheorie (bijv. zelfregulatiemodellen).

In deel I van dit boek wordt een aantal theoretische benaderingen besproken, waarbij wordt teruggegrepen op de kennis die in deze psychologische disciplines is ontwikkeld. Van bijzondere betekenis is daarbij de psychofysiologie, mede vanwege de toepassing van moderne technieken die het mogelijk maken om allerlei fysiologische parameters ambulant en online te meten. Daar waar werknemers vroeger in een kunstmatige laboratoriumsetting onderzocht moesten worden, kan dat nu op de werkplek zelf gebeuren, zonder dat zij daarbij gehinderd worden door allerlei meetapparatuur. Deze bevindt zich in een klein kastje waarin allerlei fysiologische gegevens als hartslag, bloeddruk en ademhalingsfrequentie worden opgeslagen om daarna uitgelezen te worden. In $>$ H. 4 wordt uitgebreid ingegaan op de psychofysiologie van werkstress en op de psychoneuro-immunologie, die de wisselwerking bestudeert van (werk)gedrag, neurologische hardware en hormoonhuishouding. Beide terreinen zullen in de toekomst aan betekenis winnen. Datzelfde geldt voor de gedragsgenetica en de evolutionaire psychologie, waarbij nog nauwelijks begonnen is om deze toe te passen op werkgedrag. Zo zou de laatstgenoemde benadering bijvoorbeeld gebruikt kunnen worden om (conflictueuze) sociale relaties op het werk beter te begrijpen, zoals uitsluiten en pesten op het werk (zie $>$ H. 24).

Naast het ontwikkelen van verklarende (fysiologische) theorieën over welzijn en gezondheid op het werk, is het ook van belang dat er nieuwe concepten worden ontwikkeld die aansluiten bij veranderingen die zich in de wereld van de arbeid voltrekken. Zo zal er in de toekomst vooral behoefte zijn aan begrippen om emotionele en cognitieve werkbelasting te beschrijven, juist omdat deze soorten van belasting sterk zullen toenemen. Burnout (zie $>$ H. 17) is een begrip dat daaraan tegemoetkomt, evenals emotionele arbeid (zie $>$ H. 13). Vanwege de toegenomen arbeidsparticipatie van vrouwen en vanwege het steeds meer in elkaar overlopen van werk en vrije tijd is het daarnaast van groot belang om over begrippen te beschikken als werk-thuisinterferentie, spillover en crossover (zie $>$ H. 14 en $>$ H. 21). Juist omdat er allerlei grenzen wegvallen, niet alleen tussen werk en vrije tijd, maar ook tussen thuis en kantoor denk daarbij aan de opkomst van Het Nieuwe Werken - is het in toenemende mate van belang dat werknemers hun eigen grenzen stellen. Het niet respecteren daarvan kan bijvoorbeeld resulteren in werkverslaving (zie H. 18), oftewel dwangmatig hard en veel werken. 
De wellicht de meest ingrijpende en veelbelovende ontwikkeling in de A\&G-psychologie is het toepassen en verder ontwikkelen van inzichten uit de positieve psychologie bij werknemers in organisaties. Deze tak van de psychologie richt zich op het bestuderen en bevorderen van condities voor optimaal functioneren van mensen in plaats van op hun problemen, stoornissen en disfunctioneren. Een voorbeeld van deze nieuwe aanpak die sinds de eeuwwisseling opgeld doet, is de verschuiving van burnout naar bevlogenheid (zie $>$ H. 17). Traditioneel was de A\&Gpsychologie vooral gericht op de vier D's gericht - Disease, Disorder, Damage, Disability - en was daarmee feitelijk een psychologie van arbeid en ongezondheid. Door de positieve psychologie te omarmen doet de A\&G-psychologie dus eindelijk zijn naam eer aan. Het feit dat de belangstelling voor een positieve benadering in de A\&G-psychologie zich juist nu voordoet is niet toevallig en hangt samen met allerlei veranderingen in en rondom de arbeid. Deze hebben tot gevolg dat de fysieke inzet van werknemers steeds meer plaats maakt ten gunste van hun psychologische inzet. Zo vergen bijvoorbeeld de nadruk op klantvriendelijkheid, werken in teamverband, diversiteit op de werkvloer en de invoering van Het Nieuwe Werken, veel van het aanpassingsvermogen en van de instelling, motivatie en sociale vaardigheden van werknemers. Zij dienen flexibel, toegewijd, loyaal, energiek, leergierig, enthousiast en proactief te zijn, en over goede communicatie, onderhandelings- en timemanagement vaardigheden te beschikken. Kortom, een werknemer die 'slechts' gezond is, dat wil zeggen vrij van klachten en die niet verzuimt, komt al lang niet meer tegemoet aan wat de organisatie vraagt. Moderne arbeidsorganisaties hebben bevlogen werknemers nodig die met inzet, overgave en passie hun werk doen en indien nodig, ook een stapje meer. Men zou kunnen zeggen dat er sprake is van een zekere psychologisering van organisaties, dat wil zeggen dat het bedrijfsresultaat in toenemende mate afhankelijk is van de affectieve, cognitieve, gedragsmatige en motivationele kenmerken van werknemers. Dat betekent tegelijkertijd dat de waarde van het menselijke kapitaal - vooral in de vorm van mentaal kapitaal - sterk is toegenomen. Het zijn de mensen, en meer specifiek hun mentale eigenschappen en vermogens, die vandaag de dag voor organisaties het verschil maken. En het op peil houden en indien mogelijk verhogen van dat mentale kapitaal vormt de belangrijkste toekomstige uitdaging voor de A\&G-psychologie.

Voorts ligt er een uitdaging voor de A\&G-psychologie om de onderzoeksresultaten die tot nu toe zijn gevonden in cross-sectioneel onderzoek met hoofdzakelijk zelfrapportagevragenlijsten, te repliceren in longitudinaal onderzoek en kwantitatief dagboekonderzoek (zie - H. 10), waarbij ook gebruik wordt gemaakt van meer objectieve gegevens zoals lichamelijke reacties (zie $>$ H. 4), geregistreerd ziekteverzuim (zie $>$ H. 20), en arbeidsprestatie (zie $>$ H. 19). Het is met name van belang om aan te tonen dat de werkbeleving van werknemers, inclusief de ervaren klachten en problemen, van invloed zijn op meetbare (objectieve) grootheden die een rol spelen bij de bedrijfsvoering. Pas wanneer organisaties overtuigd kunnen worden van het feit dat de mentale conditie van hun personeel van directe invloed is op het bedrijfsresultaat, zullen zij bereid zijn daarin te investeren. Slaagt de A\&G-psychologie daar niet in, dan zal zij slechts een marginale rol kunnen spelen. Dit impliceert overigens dat A\&G-psychologen meer dan nu het geval is met andere disciplines moeten samenwerken (bijv. met economen en bedrijfskundigen) op het vlak van kosten-batenanalyse van interventies; een tot op heden nagenoeg onontgonnen terrein. Een veelbelovend voorbeeld van zo'n multidisciplinaire aanpak is HR-analytics (Fitz-enz, 2010), waarbij subjectieve, psychologische gegevens van werknemers, die met behulp van enquêtes zijn verkregen, gekoppeld worden aan relevante bedrijfsresultaten. Op die manier kan bijvoorbeeld worden vastgesteld in hoeverre bevlogen werknemers bijdragen aan klanttevredenheid, bedrijfswinst of marktaandeel.

Vanuit het perspectief van de beroepsbeoefenaars bestaat er een grote behoefte aan instrumenten, richtlijnen en procedures met betrekking tot assessment, zowel op individueel 
niveau (zie $>$ H. 5) als op organisatieniveau (zie H. 6). Voorts blijft er behoefte bestaan aan interventiemethoden op individueel niveau (zie H. 7) en organisatieniveau (zie H. 9), inclusief de arbeidsre-integratie (zie $>$ H. 8), een terrein dat steeds meer in belang toeneemt. Naast klachtreductie vormt werkhervatting namelijk een tweede, gelijkwaardige behandelingsdoelstelling van werknemers met psychische problemen. In toenemende mate richten interventies zich ook op het optimaliseren en verbeteren van gezondheid, welbevinden en prestatie van werknemers. Deze positieve benadering wordt in navolging van curatie (behandelen) en preventie (voorkomen) ook wel 'amplitie' genoemd. In de praktijk krijgt amplitie vorm door het bevorderen van vitaliteit, bevlogenheid en duurzame inzetbaarheid van medewerkers. Vooral bij organisatie-interventies gaat het niet alleen om inhoudelijke en methodische kennis, maar ook om kennis over de implementatie van maatregelen. Het transformeren van theoretische kennis naar praktisch handelen is een cruciaal onderdeel van de A\&G-psychologie. Het instrumentarium dient uiteraard van goede kwaliteit te zijn, dus 'evidence-based' en gestoeld op wetenschappelijk onderzoek.

Voor wat betreft assessment is de predictieve validiteit ofwel het voorspellend vermogen van een instrument van cruciaal belang. Bijvoorbeeld: in hoeverre voorspelt een bepaalde test het toekomstige ziekteverzuim of de toekomstige arbeidsprestatie? Daarenboven dient er nog veel werk te geschieden op het vlak van normering: een bepaalde score krijgt immers pas betekenis wanneer deze vergeleken wordt met een referentiescore (zie $>$ H. 5 en $\triangleright$ H. 6). Echter, dergelijke referentiescores ontbreken momenteel nog bij veel assessmentinstrumenten. Wat interventies betreft is er nog steeds behoefte aan gedegen effectonderzoek. Alhoewel effectonderzoek talloze voetangels en klemmen kent (zie $>$ H. 11), is het daarom niet minder noodzakelijk.

Het is al eerder gezegd: bij de A\&G-psychologie gaat het zowel om kennis als om kunde, om denken en doen, om theorie en praktijk. Maar bovenal gaat het om de integratie van beide: om een wetenschappelijk gefundeerde beroepspraktijk en om een beroepsrelevante wetenschapspraktijk. Dat maakt de A\&G-psychologie tot een heel complexe maar tegelijk ook spannende onderneming. Met dit leerboek hopen wij diegenen een dienst te bewijzen die zich willen verdiepen in haar wetenschappelijke grondslagen en praktische toepassingen.

\section{Aanbevolen literatuur}

Bakker, A.B., \& Derks, D. (2010). Positive Occupational Health Psychology. In S. Leka \& J. Houdmont (Eds.), Occupational health psychology: A key text (pp. 194-224) Oxford: Wiley-Blackwell.

Barling, J., \& Griffiths, A. (2010). A history of occupational health psychology. In J. C. Quick \& L. E. Tetrick (Eds.), Handbook of occupational health psychology, 2nd ed. (pp. 21-34). Washington, DC: APA Books.

Cooper, C.L., \& Dewe, P. (2004). Stress: a brief history. Malden, MA: Blackwell.

Schaufeli, W.B. (2004). The future of occupational health psychology. Applied Psychology: An International Review, 53, 502-517.

Schaufeli, W.B., \& Bakker, A.B. (2001). Werk en welbevinden: naar een positieve benadering in de arbeids- en gezondheidspsychologie. Gedrag en Organisatie, 14, 229-253.

Aanbevolen websites

Arbowetgeving: www.arboportaal.nl

European Academy of Occupational Health Psychology: $>$ www.eaohp.org

Journal of of Occupational Health Psychology: www.apa.org/pubs/journals/ocp/

Nederlands Instituut vanPsychologen (NIP): www.psynip.nl

Society of of Occupational Health Psychology: http://sohp.psy.uconn.edu/

Work \& Stress: $>$ www.tandf.co.uk/journals/tf/02678373.html 